\title{
Community perspectives of governance for effective management of marine protected areas in Malaysia
}

\begin{abstract}
Marine Protected Areas (MPAs) are useful tool for conserving biodiversity and managing fisheries. The government of Malaysia has established several Marine Protected Areas (MPAs) to enable overexploited marine resources to recover and to conserve coral reef ecosystems.

The paper investigates the effect of governance approach on the effective management of two MPAs, Perhentian and Kapas marine parks in Terengganu State of Peninsular Malaysia. The data for this study was obtained from face-to-face interviews with local people from two MPAs using a structured questionnaire. The results of the analysis show that local participation in MPA management and fisheries regulations are significant factors for the effective MPA management in the study areas. The regression results show that users' participation has contributed significantly to the MPA governance, which indicate that local peoples' participation play an important role for effective management of MPAs in Malaysia. The MPA management activities should be coordinated with other relevant agencies and local users to achieve successful management of MPAs in Malaysia. There is a need to give priority to encourage local fishers' participation in decision making for MPAs management in the future marine resource conservation policy in Malaysia.
\end{abstract}

Keyword: Marine protected areas; Coral reefs; Governance; Participation; Management capacity; Peninsular Malaysia 